\begin{tabular}{|c|l|}
\hline Title & $\begin{array}{l}\text { Subglacial drainage system changes of the Gulkana Glacier, A laska: discharge and sediment load observations and } \\
\text { modelling }\end{array}$ \\
\hline Author(s) & Kido, Daisaku; Chikita, Kazuhisa A.; Hiray ama, Kenta \\
\hline Citation & $\begin{array}{l}\text { Hydrological Processes, 21(3), 399-410 } \\
\text { https://doi.org/10.1002/hyp.6364 }\end{array}$ \\
\hline Issue Date & 2007-01-30 \\
\hline Doc URL & http://hdl.handle.net/2115/20006 \\
\hline Rights & Copyright $\odot$ 2007 John Wiley \& Sons, Inc., Hydrological Processes, Volume 21, Issue 3, Pages 399-410 \\
\hline Type & article (author version) \\
\hline File Information & HP21-3.pdf \\
\hline
\end{tabular}

Instructions for use 


\section{Subglacial drainage system changes of the Gulkana Glacier, Alaska: discharge and sediment load observations and modeling}

Daisaku Kido, Kazuhisa A. Chikita* and Kenta Hirayama

Division of Earth and Planetary Sciences, Graduate School of Science, Hokkaido University, Sapporo 060-0810, Japan

*Correspondence to: Kazuhisa A. Chikita, Division of Earth and Planetary Sciences, Graduate School of Science, Hokkaido University, Sapporo 060-0810, Japan.

E-mail: chikita@ep.sci.hokudai.ac.jp

Abstract:

Hydrological characteristics of englacial and subglacial drainage systems in Gulkana Glacier, Alaska, were examined by analyzing temporal variations of water and sediment discharges in the proglacial Phelan Creek in 2001. From data plots on semi-log paper, it appeared appropriate to separate both discharge and sediment load into fast and slow components. The two components were possibly produced by two different drainage systems: an englacial and subglacial, "channelized" system in the ablation zone, and a subglacial, "distributed" system in the accumulation zone. The data 
indicate the occurrence of an event during which part of the "distributed" drainage system changed into the "channelized" drainage system. The daily time series of discharge and sediment load were represented using a tank model. In the model, the drainage from an additional tank was added, supposing that a subglacial reservoir full of water and sediment collapsed slowly when the subglacial drainage system changed from distributed to channelized. The simulation with the collapsed tank gave much more reasonable results than those with no collapsed tank. The contribution of the collapsed tank to total sediment load is $24 \%$, which is much larger than $9 \%$ to total discharge.

KEY WORDS glacier-melt; discharge; suspended sediment; Gulkana Glacier; subglacial drainage system; tank model

\section{INTRODUCTION}

The sediment load from a glacier-covered drainage basin is generally greater than that from a similarly sized basin with no glacial cover, because of the high sediment erosion by glacial motion (Gurnell et al., 1996; Alley et al., 1998). The sediment discharge from glacier-melt, however, varies widely for any particular water discharge (e.g., Willis et al., 1996; Anderson and Humphery, 1999). This is thought to reflect variations in 
sediment supply as meltwater pathways change and subglacial erosion rates vary. In the case of temperate glaciers, high subglacial water pressures are caused by the rapid melt at the glacier surface and subsequent englacial water storage in early summer. The release of this water is thought to induce a change in the subglacial drainage system from a "distributed" to "channelized" structure, with a gradual migration of the latter upglacier during the melt season (e.g., Fountain and Walder, 1998; Hubbard and Nienow, 1998; Nienow et al., 1998). Some researchers have suggested that the distributed drainage system exists as a linked-cavity network that tends to retard meltwater movement so that it acts as a main pathway for slow water flow (Kamb, 1987; Walder and Fowler, 1994; Fountain and Walder, 1998; Hubbard and Nienow, 1998). Flow separation of melt discharge has been performed using conceptual reservoir models or chemically-based mixing models, in order to identify the changing storage characteristics of the glacial drainage systems and to attribute flow to reservoirs with different hydrological response times (e.g., Gurnell, 1993; Wagnon et al., 1998; Hannah and Gurnell, 2001; Matsumoto, 2003).

In the present study, discharge and sediment load from the basin of the temperate Gulkana Glacier, Alaska, are reproduced numerically by a tank model (Sugawara, 1972, Yue and Hashino, 2000), and the model is used to explore the relationship between the glacial drainage systems and the discharge and sediment load. The tank model is a river 
runoff model applied to rainfall runoff and snowmelt runoff in a non-glacierized drainage basin (e.g., Mizunuma and Chiu, 1985), and the linear reservoir model applied to glacier-melt runoff (e.g., Hannah and Gurnell, 2001) corresponds to a modified type of tank combination (Sugawara, 1972).

\section{STUDY AREA AND METHODS}

Figure 1 shows the location of Gulkana Glacier, Alaska (63 $\left.{ }^{\circ} 16^{\prime} \mathrm{N}, 145^{\circ} 25^{\prime} \mathrm{W}\right)$ and the observation sites in the $31.1 \mathrm{~km}^{2}$ drainage basin upstream of the gauging station (site PC at $1125 \mathrm{~m}$ asl) on the proglacial Phelan Creek, a tributary of the Delta River. The study basin is located in the mountainous headwater region of the Delta River, which is a tributary of the Tanana River. The Tanana River contributes a large amount of suspended sediment to the Yukon River as a result of glacial erosion (Chikita et al., 2002). The average equilibrium line altitude of the glacier was $1770 \mathrm{~m}$ asl between 1967 and 1993 (March, 2000). In the summer of 2001, when water turbidity was monitored for the present study, most of the meltwater discharge occurred in three proglacial channel outlets, which merged into a single river channel ca. 800m upstream of site PC (Figure 1). Water discharge on days of no rainfall is assumed to be constant between the glacier terminus and site PC, since meltwater inflow from snow or dead ice is negligible. In the non-glacial region, there is no vegetation cover on the glacial till. 
Since 1967, air temperature and rainfall have been monitored at site WS (1480 m asl) and site PC. The mean annual precipitation is ca. $1000 \mathrm{~mm}$ and mean air temperature is $-2^{\circ} \mathrm{C}$ at site WS. River stage has been measured at site PC by the US Geological Survey. A rating curve is re-established every year by occasional measurements of stage and discharge at site PC. The measured discharge is within \pm $5 \%$ of discharge estimates obtained using the rating curve. The mean annual discharge from 1967 to 2000 is $5.87 \times 10^{7} \mathrm{~m}^{3}$, of which $86 \%$ occurs from June to August. For the present study, turbidity was monitored hourly at site PC between 29 June and 31 August 2001, using a self-recording, infrared back-scattering turbidimeter (Alec Electronics, Inc., model MTB-32K; accuracy $\pm 24 \mathrm{ppm}$ with a range of 0 to $2000 \mathrm{ppm}$ ) near the bank. The turbidity was recorded ten times every hour with a sampling interval of $1 \mathrm{~s}$, and the ten samples were averaged to obtain an hourly value. The averaged turbidity values were converted to suspended sediment concentrations (mg l${ }^{-1}$ ), using the relationship ( $r^{2}=0.846$ ) between turbidity and simultaneous measurements of suspended sediment concentration obtained from filtration of river water samples. suspended sediment concentration was measured by sampling river water with a DH-48 depth-integrating sampler, and filtering the samples through $0.45 \mu \mathrm{m}$ pore size glass-fiber filters. A time series of sediment load, $S\left(\mathrm{~g} \mathrm{~s}^{-1}\right)$ was obtained from the product of the discharge, $Q\left(\mathrm{~m}^{3} \mathrm{~s}^{-1}\right)$ and suspended sediment concentration, $C\left(\mathrm{~g} \mathrm{~m}^{-3}\right)$, 
i.e. $S=Q \cdot C$.

Time series of daily discharge and sediment load at site PC were used to explore the relationship between discharge, sediment load, and water distribution within the glacier. The tank model used in this study was originally designed for analyzing discharge time series from a non-glacierized drainage basin (Motoyama et al., 1983; Mizunuma and Chiu, 1985; Yue and Hashino, 2000), but is applied here to discharge and sediment load from a glacierized basin by treating the basin output as the sum of the contributions of two drainage systems.

In order to examine a mixing condition of suspended sediment, vertical profiles of flow velocity were obtained at site PC by using an electromagnetic current meter, and the grain size analysis of suspended sediment in sampled water was performed by the sieving and gravitational settling methods. The validity of the tank model for sediment load calculations was suggested by a condition that the suspended sediment of more $95 \%$ silt and clay is under complete suspension on the extended Shields diagram (Chikita et al., 2002).

\section{OBSERVATIONS AND DISCUSSION}

Discharge, sediment load and meteorology

Figure 2 shows time series of discharge and sediment load, suspended sediment 
concentration, air temperature and rainfall at site PC for the period of 27 June to 4 September 2001. For most of this period, both discharge and suspended sediment concentration exhibited diurnal variations, even during days of rainfall, discharge lagged air temperature by a $2 \mathrm{~h}$, and the peak suspended sediment concentration preceded the peak discharge by 1 to $3 \mathrm{~h}$ on days of no rainfall. During two periods, 19 27 July and 29 July - 1 August, the suspended sediment concentration and discharge increased greatly in response to high daily air temperatures (reaching $22.1{ }^{\circ} \mathrm{C}$ on 18 July) and in the case of the second period, prolonged rainfall (30 July - 1 August). The 19-27 July event exhibited more than two peaks per day in both suspended sediment concentration and discharge. The peak of suspended sediment concentration occurred during increasing discharge, and the suspended sediment concentration subsequently decreased faster than discharge. This suggests that part of the subglacial drainage system changed drastically during the event and released subglacial sediments (see Tranter et al., 1996; Hannah and Gurnell, 2001). The sediment rating curve data (Figure 3) indicate that the observations during the 19-27 July event are located on or above the regression line (symbol $\times$ ), showing that the suspended sediment concentration was high with respect to the discharge, possibly indicating the entrainment of sediment as the drainage system changed from a distributed to a more channelized form.

During the second event of 29 July - 1 August, the peaks in discharge and 
suspended sediment concentration occurred synchronously. The peak discharge was comparable in magnitude to that of the 19 - 27 July event, whereas the peak suspended sediment concentration was relatively small. As a result, the observations lie on or near the rating curve (symbol in Figure 3), indicating a reduced availability of subglacial sediment in the glacial drainage system after its restructuring in response to the first event. Before the first event, suspended sediment concentration alone increased in response to rainfall. Afterwards, however, suspended sediment concentration and discharge both responded rapidly, indicating a more efficient glacial drainage system.

According to observations at the Black Rapids Glacier, located ca. $50 \mathrm{~km}$ northwest of Gulkana Glacier (Raymond et al., 1995), glacial hydrological events can be classified into two types, one resulting from the glacier-wide input of extra water associated with weather events (type I), and the other associated with localized and gradual build-up of water in internal reservoirs released suddenly by internal processes (type II). Here, the first event (19 to 27 July) and the second event (29 July to 1 August) could correspond to type II and type I, respectively.

Decay constants for discharge and sediment load Discharge and suspended sediment concentration varied diurnally for most of observation period (Figure 2). Sediment load, the product of discharge and suspended 
sediment concentration, therefore, also varies diurnally. The declining limb of the diurnal hydrograph can often be partitioned into two or three linear sections on semi-log paper (e.g., Gurnell, 1993; Hannah and Gurnell, 2001).

Figure 4 shows typical falling limbs of discharge, $Q$, and sediment load, $S$, for three periods, corresponding to the early, middle and late stages of glacier-melt for periods of 29 June to 19 July (before the two high magnitude events), 2 to 11 August (within 10 days after the events) and 21 to 31 August (more than 20 days after the events), respectively (see Figure 2). Decay constants for $Q$ and $S$ can be estimated using the following relationships.

$$
Q(t)=Q_{0} \cdot \exp \left(-t / T_{w}\right)
$$

and

$$
S(t)=S_{0} \cdot \exp \left(-t / T_{s}\right)
$$

where $t$ is the elapsed time (h), $Q_{0}$ and $S_{0}$ are the discharge and sediment load at $t=0$, and $T_{w}$ and $T_{s}$ are the decay constants for water and sediment discharges, respectively. In Figure 4, discharge and sediment load are both separated into two linear sections, where each linear section is made up of at least 3 consecutive hourly observations and linear regression is used to estimate the decay constants (regression models were accepted where $r^{2}>0.880$, since the plots with $r^{2}<=0.88$ seemed to give a more separate component on semi-log paper). When separation of discharge and sediment load into the two components is achieved, it suggests that fast and slow flow components operate 
at the same time and independently access sediment sources. In Figure 4, the decay constants for discharge are $T_{w}{ }^{\text {fast }}=10.1,19.4$ and $13.6 \mathrm{~h}$ for the fast component and $T_{w}^{\text {slow }}=47.6,43.1$ and $32.6 \mathrm{~h}$ for the slow component. Meanwhile, the decay constants for sediment load in Figure 4 are $T_{s}{ }^{\text {fast }}=3.26,7.66$ and $3.60 \mathrm{~h}$ for the fast component and $T_{s}^{\text {slow }}=24.0,26.2$ and $14.0 \mathrm{~h}$ for the slow component. Hence, sediment load decreases faster than discharge, probably reflecting a decrease in sediment availability or shear stress during declining flows, since sediment load depends on suspended sediment concentration rather discharge (see Figure 2).

In the early, middle and late stages of glacier-melt, the mean \pm standard deviation of the decay constants was evaluated at $T_{w}{ }^{\text {fast }}=6.2 \pm 12.8 \mathrm{~h}, 5.5 \pm 21.2 \mathrm{~h}$ and $3.7 \pm 13.7$ h, $T_{w}^{\text {slow }}=11.4 \pm 42.4 \mathrm{~h}, 28.0 \pm 65.4 \mathrm{~h}$ and $11.6 \pm 35.9 \mathrm{~h}, T_{s}^{\text {fast }}=4.9 \pm 2.8 \mathrm{~h}, 10.1 \pm 4.0 \mathrm{~h}$ and 7.3 $\pm 4.2 \mathrm{~h}$, and $T_{s}^{\text {slow }}=20.7 \pm 17.7 \mathrm{~h}, 36.9 \pm 10.7 \mathrm{~h}$ and $21.9 \pm 6.3 \mathrm{~h}$, respectively. The decay constants of discharge thus exhibited greater variations than those of sediment load, and of all the decay constants, $T_{w}{ }^{\text {slow }}$ was relatively unstable throughout the glacier-melt season. The mean decay constants in the modes of frequency distributions were estimated at $T_{w}^{\text {fast }}=17 \mathrm{~h}, T_{w}^{\text {slow }}=31 \mathrm{~h}, T_{s}^{\text {fast }}=3.4 \mathrm{~h}$ and $T_{s}^{\text {slow }}=13 \mathrm{~h}$. It is unknown why there were no clear seasonal variations of the decay constants, $T_{w}{ }^{\text {fast }}$ and $T_{w}^{\text {slow }}$, though the fast and slow discharges likely reflect the seasonal variations of water pathways in supraglacial, englacial and subglacial drainage systems. 


\section{Estimates of water input and storage}

The seasonal variation of water storage in a glacier could impact the glacial drainage system (e.g., Anderson and Humphrey, 1999), and may be reflected in the slow component of water discharge, if the water input by glacier-melt and rainfall is constant.

Hence, the water input to the storage in the drainage basin were estimated using the following water budget:

$$
\Delta W=q_{m e l t} \cdot A_{g}+P \cdot A_{t}-Q_{\text {out }},
$$

where $\Delta W$ is the change in liquid water storage $\left(\mathrm{m}^{3}\right.$ day $\left.^{-1}\right), q_{\text {melt }}$ is the rate of snowmelt or ice-melt at the glacier surface (m day ${ }^{-1}$ ), $A_{g}$ and $A_{t}$ is the glacier surface area and the drainage area $\left(\mathrm{m}^{2}\right)$, respectively, $P$ is the rainfall $\left(\mathrm{m} \operatorname{day}^{-1}\right)$, and $Q_{\text {out }}$ is the discharge $\left(\mathrm{m}^{3}\right.$ day $\left.^{-1}\right)$. In Equation (3), the evaporation and sublimation from the glacier surface is neglected. $q_{\text {melt }}$ is numerically obtained by applying the positive degree-day approach (Braithwaite, 1995):

$$
q_{\text {melt }}=\gamma_{\text {snow }} \overline{T_{a}} \quad \text { or } \quad q_{\text {melt }}=\gamma_{\text {ice }} \overline{T_{a}} \quad \text { for } \quad \overline{T_{a}} \geqq 0
$$

and

$$
q_{\text {melt }}=0 \quad \text { for } \overline{T_{a}}<0 \text {, }
$$

where $\gamma_{\text {snow }}$ and $\gamma_{\text {ice }}$ are the empirical constants for snowmelt and ice-melt at the glacier surface, respectively, and $\overline{T_{a}}$ is the daily mean air temperature $\left({ }^{\circ} \mathrm{C}\right)$. Considering $\gamma_{\text {snow }}=3.5-5 \mathrm{~mm}$ day ${ }^{-1}{ }^{\circ} \mathrm{C}^{-1}$ and $\gamma_{\text {ice }} \sim 2 \gamma_{\text {snow }}$ for Gulkana Glacier 
(March, 2000) and the relatively small solar radiation at a certain air temperature in August, $\gamma_{\text {snow }}=4.0 \mathrm{~mm}$ day ${ }^{-1}{ }^{\circ} \mathrm{C}^{-1}$ and $\gamma_{\text {ice }}=8.0 \mathrm{~mm}$ day $^{-1}{ }^{\circ} \mathrm{C}^{-1}$ in June to July and $\gamma$ snow $=3.5 \mathrm{~mm} \mathrm{day}^{-1}{ }^{\circ} \mathrm{C}^{-1}$ and $\gamma_{\text {ice }}=7.0 \mathrm{~mm} \mathrm{day}^{-1}{ }^{\circ} \mathrm{C}^{-1}$ in August were here adopted.

Using the contour lines with a 100 m interval on the glacier in Figure1, and considering a decrease of $0.66^{\circ} \mathrm{C}$ per $100 \mathrm{~m}$ in altitude (March, 2000), the glacier-melt rate $\left(q_{\text {melt }}\right)$ was estimated from the air temperature data obtained at site WS (Figure 1). Snow-covered and ice-covered areas of Gulkana Glacier were delineated using the snow line altitudes observed by Dr. N. Takeuchi (personal communication: Table 1). It was assumed that the rainfall recorded at site PC is constant within the drainage basin, and that all the rainwater onto the glacier enters into the glacier. The precipitation at $\overline{T_{a}}<0$ is considered to make no contribution to the recharge. For discharge, $Q_{\text {out }}$, in Equation (3), the discharge data at site PC were used.

Figure 5 shows daily variations of total water input, $q_{\text {melt }}+P$, cumulative water storage, $\sum\left(\Delta W / A_{t}\right)$, and specific discharge, $q_{\text {out }}\left(=Q_{\text {out }} / A_{t}\right)$ in $\mathrm{mm} \mathrm{d}^{-1}$, where $A_{t}=31.1$ $\mathrm{km}^{2}$ for Gulkana Glacier. The cumulative water storage is assumed to be zero at 00:00 on 1 June, and thus is probably underestimated over the period of calculation. The first event (19 to 27 July) started the day before the peak in the cumulative water storage, and water storage rapidly decreased from 20 July. The second event (29 July to 1 August) was likely induced by the simultaneous rainfall, because $P$ - $\Delta S / A_{g}$ from 
Equation 3 was then comparable in magnitude to $q_{\text {out }}$.

\section{MODELLING}

Utilizing the total water input and the decay constants of fast and slow components, the discharge and sediment load time series of the Gulkana Glacier basin were simulated using a tank model, and the modeled results were compared with the observation.

\section{Discharge}

Figure 6 shows the combination of tanks used in the discharge simulation. The drainage basin was divided into three different regions, snow-covered, ice-covered and non-glacial regions. The water input, $I_{\text {snow }}$, and the subglacial discharge, $Q_{\text {slow }}$, in the snow-covered region occur in the upper left tank in Figure 6, and the discharge, $Q_{\text {slow }}$, from the upper tank is connected to the lower tank in addition to the water input, $I_{\text {ice }}$, in the ice-covered region. The discharge from glacial tills and exposed bedrock in the non-glacial region occurs in response to rainfall, and the right upper and lower tanks produce the fast component (surface flow), $Q_{n 1}$, and the slow component (base flow), $Q_{n 2}$, respectively (Yue and Hashino, 2000). Water discharge, $Q_{g l}$, from the left lower tank is equivalent to total discharge from the glacier-covered region. On days of rainfall, the drainage $\left(Q_{n 1}\right.$ and $\left.Q_{n 2}\right)$ from the right tanks is added to $Q_{g l}$. It was assumed that any 
rainwater onto the non-glacial region does not contribute to the water input and storage in the glacier-covered region, but flows directly to site PC. A relation between a discharge, $Q_{i}\left(Q_{s l o w}, Q_{g l}, Q_{n 1}, Q_{n 1-2}\right.$ or $Q_{n 2}$ in Figure 6), from a tank and water storage, $W_{i}\left(W_{\text {slow }}, W_{g l}, W_{n 1}\right.$ or $\left.W_{n 2}\right)$, in the tank is given by the following equation:

$$
Q_{i}=D_{i} \cdot W_{i}(t)
$$

where $D_{i}$ is the discharge coefficient $\left(D_{\text {slow }}, D_{g l}, D_{n 1}, D_{n 1-2}\right.$ and $\left.D_{n 2}\right) . W_{i}(t)$ is obtained by the equation of continuity:

$$
\frac{d W_{i}(t)}{d t}=I_{i}(t)-Q_{i}(t),
$$

where $I_{i}(\mathrm{t})$ is the water input $\left(I_{\text {snow }}, I_{i c e}, I_{n 1}, Q_{\text {slow }}\right.$ or $\left.Q_{n 1-2}\right)$ for snow-covered, ice-covered and non-glacial regions, and from the upper tanks. The discharge coefficients, $D_{\text {slow }}$ and $D_{g l}\left(=1 / T_{w}\right.$, where $T_{w}$ is the decay constant for water discharge), were determined from the decay constants of $T_{w}^{\text {fast }}=6.3$ to $21.8 \mathrm{~h}$ and $T_{w}^{\text {slow }}=22.6$ to $97.1 \mathrm{~h}$ so that the simulation provides the best fit for the observation. The fast component, $Q_{\text {fast }}$, from the ice-covered region was given by simulated discharge, $Q_{g l}$, minus the slow component, $Q_{\text {slow }}$, from the snow-covered region.

Figure 7 shows a comparison between simulated total discharge, $Q\left(=Q_{g l}+Q_{n 1}+\right.$ $\left.Q_{n 2}\right)$, its three components, $Q_{\text {fast }}, Q_{\text {slow }}$ and $Q_{n}\left(=Q_{n 1}+Q_{n 2}\right)$, and observed total discharge. Table 2 indicates the discharge coefficients used for the best fit. In spite of the uncertainties in the estimation of the inputs and the constant discharge coefficients, 
the modeled results are consistent with the observed data $\left(r^{2}=0.566\right)$ except for the two events of 19 to 27 July and 29 July to 1 August. Prior to these events, the modeled discharge is consistently larger than the observed one. This means that the water input is larger than the observed discharge, and thus some water storage with no contribution to the discharge occurs in another tank.

Based on the assumption that the events were controlled by the collapse of an isolated tank, an additional tank was added to the system (Figure 8) and the discharge was recalculated. Prior to the discharge peak of 22 July, the total water input was $15 \%$ larger than the observed total discharge (Figure 7). The surplus water input for this period was added to the isolated tank so that the slow component, $Q_{\text {slow }}$, prior to 22 July was thus totally reduced by $15 \%$. The discharge coefficient, $D_{\text {collapse, }}$ of the isolated tank was set to $0.01 \mathrm{~h}^{-1}$ based on the decay constant during the events (Table 2).

Figure 9 shows a comparison between recalculated total discharge, four components, $Q_{\text {fast }}, Q_{\text {slow }}, Q_{n}$ and $Q_{\text {collapse }}$ and observed discharge. The recalculation reproduces observed discharge series over the observation period with $r^{2}=0.869$. Until the end of the first event (29 July), the reproduction is more significant $\left(r^{2}=0.929\right)$, but after the event, is less satisfactory $\left(r^{2}=0.736\right)$. The lower correlation possibly results from the assumption of constant rainfall within the drainage basin and from the instability of the decay constants in the middle and late stages of glacier-melt. For 
example, the calculated peak on 2 August was due to a rainfall recorded at site PC

(Figure 2), but no peak was observed, so possibly no rainfall occurred on the glacier.

The contribution of each component to the total discharge is $45 \%$ and $41 \%$ for fast and slow components from the glacier-covered region, $9 \%$ for drainage from a collapsed tank, and $6 \%$ for the non-glacial region. Discharge from a glacier-covered region is thus dominant, indicating the similar contribution in the snow-covered and ice-covered areas.

\section{Sediment load}

The reproduction of the sediment load time series was attempted using a tank model as used in other studies (Osawa and Sakai, 2002).

Figure 10 shows the tank model for sediment load, which includes the collapse of a subglacial reservoir during the events. It is basically the same tank combination as for discharge (Figure 6). Two approaches, “rating” and "separation”, were adopted for the reproduction of the sediment load time series. In the rating approach, the sediment rating curve in Figure 3 was used to obtain the suspended sediment concentration for daily mean values $\left(\mathrm{m}^{3} \mathrm{~s}^{-1}\right)$ of the simulated discharge, $Q$ (Figure 9). The suspended sediment concentration, $C_{\text {collapse }}(\mathrm{mg} / \mathrm{l})$, for the first event was given by Equation (7).

$$
C_{\text {collapse }}(n)=C_{\text {collapse }}(0) \cdot(\alpha)^{n} \text {, }
$$


where $C_{\text {collapse }}(n)$ is the suspended sediment concentration on the $n$th day from a start of the first event ( $n=0$ on 19 June), and $\alpha$ is the empirical constant. Here, $C_{\text {collapse }}(0)$ was given $4900 \mathrm{mg} \mathrm{l}^{-1}$ from the observation (see Figure 2), and $\alpha=0.78$ was adopted as the best fit for the observation. The sediment load, $S_{\text {collapse }}$, from the collapsed tank was calculated from $S_{\text {collapse }}=C_{\text {collapse }} \cdot Q_{\text {collapse }}$.

In the "separation" approach, assuming different sediment concentration values for fast and slow components from a glacier-covered region and those from a non-glacial region, corresponding sediment loads were calculated. In order to simulate the sediment load from the lower tank in a glacier-covered region, it is assumed that the sediment supplied from the upper tank is released from the lower tank with no deposition. In a non-glacial region, only the sediment load corresponding to the total discharge, $Q_{n}$, was simulated. Separately, sediment load, $S\left(\mathrm{~g} \mathrm{~s}^{-1}\right)$, is calculated from the discharge and suspended sediment concentration as follows:

$$
S(t)=Q(t) \cdot C(t),
$$

where $t$ is the elapsed time (h). Similar to Equations (1) and (2), $C(t)$ is given by

$$
C(t)=C_{0} \cdot \exp \left(-t / T_{c}\right),
$$

where $T_{c}$ is the decay constant for suspended sediment concentration, and $C=C_{0}$ at $t=$ 0. From Equations (1), (2), (8) and (9), $T_{c}$ can be expressed as follows:

$$
T_{c}=T_{s} \cdot T_{w} /\left(T_{w}-T_{s}\right) .
$$


Applying the mean values of $T_{s}(=3.4 \mathrm{~h}$ for fast and $13 \mathrm{~h}$ for slow $)$ and $T_{w}(=17 \mathrm{~h}$ for fast and $31 \mathrm{~h}$ for slow) in the highest frequencies, $T_{c}^{\text {fast }}=4.3 \mathrm{~h}, T_{c}^{\text {slow }}=22 \mathrm{~h}$ were obtained. Daily values for $C_{0}$ in Equation (9) was calculated by using a daily $Q_{0}(=Q(t$ $=0)$ ) from the simulation of discharge in $C=a Q^{b}$ (Figure 3), where $a$ and $b$ are empirical coefficients. $a$ and $b$ for each component from glacier-covered and non-glacial regions were determined for the observation period so that calculated total sediment discharge gives the best fit for the observation. Given $a, b$ and $C_{0}$ values, each sediment discharge can be calculated by the following.

$$
\begin{aligned}
& S_{\text {slow }}(t)=Q_{\text {slow }}(t) \cdot C_{\text {slow }}=Q_{\text {slow }}(t) \cdot a_{1} Q_{0 \text { slow }}^{b_{1}} \cdot \exp \left(t / T_{c}^{\text {slow }}\right), \\
& S_{g l}(t)=Q_{g l}(t) \cdot C_{\text {fast }}(t)=Q_{g l}(t) \cdot a_{2} Q_{0 \text { fast }}^{b_{2}} \cdot \exp \left(t / T_{c}^{\text {fast }}\right), \\
& S_{\text {fast }}(t)=S_{g l}(t)-S_{\text {slow }}(t), \\
& S_{n}(t)=Q_{n}(t) \cdot C_{n}(t)=Q_{n}(t) \cdot a_{3} Q_{n}^{b_{3}}, \\
& \text { and } \quad S=S_{g l}+S_{n}
\end{aligned}
$$

where $a$ and $b$ with the subscripts 1,2 and 3 are the coefficients for slow and fast components from a glacier-covered region and for a non-glacial region, respectively. $C_{\text {slow }}, C_{\text {fast }}$ and $C_{n}$ are sediment concentrations for slow and fast components from a glacier-covered region and for total discharge from a non-glacial region, respectively, whereas $Q_{0 \text { fast }}$ and $Q_{0 \text { slow }}$ are $Q_{0}$ for fast and slow components from a glacier-covered region, respectively. $C_{g l}$ from a glacier-covered region was assumed to be equal to 
suspended sediment concentration, $C_{\text {fast }}$, for the fast component.

First, the coefficients $a_{i}$ and $b_{i}(i=1,2)$, giving the best fit for observed sediment load for the fast and slow components in a non-rainfall period, were determined, and then $C_{\text {fast }}$ and $C_{\text {slow }}$ values were computed. Second, $C_{n}\left(=a_{3} Q_{n}^{b_{3}}\right)$ was numerically obtained from $a_{3}$ and $b_{3}$ giving the best fit over the observation period. The simulated discharge (Figure 9) was used for $Q_{\text {slow }}, Q_{g l}$ and $Q_{n}$ in Equations (11), (12) and (14). The sediment load from a collapsed reservoir was added as in the "rating” approach.

Figure 11 shows a comparison between simulated and observed results from the “rating” approach. The simulation reproduces the observed result well $\left(r^{2}=0.863\right.$ over the observation period), except for a calculated peak appeared on 2 August as in Figures 7 and 9. This satisfactory reproduction means the high utility of the rating curve in Figure 3 and Equation (7). It is seen that sediment load from the collapsed tank decreases more rapidly than water discharge over ca. 15 days (Figure 9).

Figure 12 shows a comparison between calculated total sediment load, $S+S_{\text {collapse, }}$ and observations for the separation approach. $a$ and $b$ values for each of $C_{\text {fast }}, C_{\text {slow }}$ and $C_{n}$, giving the best fit, are given in Table 3 . The reproducibility of this simulation $\left(r^{2}=\right.$ $0.832)$ is comparable to the rating approach $\left(r^{2}=0.863\right)$, and also the non-observed peak of 2 August in Figure 11 does not appear. The contributions of each component over the calculation period are $53 \%$ and $14 \%$ for fast and slow components from the 
glacier-covered region, $9 \%$ for the non-glacial region, and $24 \%$ for the drainage from the collapsed tank. The contribution of the collapsed tank is much larger than its $9 \%$ contribution to the discharge. This suggests that erosion of subglacial deposits by the tank collapse is more effective than the erosion in the two subglacial drainage systems. Chikita (1993) and Chikita et al. (1998) pointed out that, for sediment load of mostly silt and clay including few organic matters, the exponent $b$ is similar at a range of 2.1 2.2, if the sediment availability is enough, whereas the coefficient $a$ decreases, if the sediment includes clay minerals such as kaolinite, chlorite and montmorillonite. Some researchers have found that the coefficient $a$ in the rating curve reflects the sediment erodibility in the drainage basin (Morgan, 1995; Asselman, 2000), whereas the exponent $b$ represents the availability of sediment (e.g., Walling, 1974; Morgan, 1995). The values of $a$ and $b$ in Table 3 thus suggest that the sediment erodibility is highest for the fast component possibly flowing in the channelized drainage system, but the sediment availability is highest for the slow component possibly passing through the distributed drainage system.

\section{CONCLUSIONS AND FUTURE STUDIES}

The continuous hydrological observations in proglacial Phelan Creek and modeling suggest that the "events" of rapidly increased discharge and sediment load are due to 
the collapse of a subglacial reservoir. The events were observed twice for the period from 19 July to 1 August 2001. The time series of discharge and sediment load were well simulated by a tank model $\left(r^{2}=0.832\right.$ and 0.869$)$ in which drainage and sediment output from an isolated tank were incorporated. The occurrence of such subglacial events as observed in 2001 is probably controlled by snow accumulation and meteorological conditions during the melt season, because the meltwater input into the glacier could induce such events, increasing water pressure at the glacier base. Long-term observations of discharge and sediment load are thus needed to clarify how the climate variability could induce such events. It is unknown why the decay constants used in the tank model are insensitive to seasonal variations of the snowline altitude and drainage systems. The tank model is only conceptual, but its application should be done for observations in the other years, in order to clarify what decay constants reflect in the drainage systems.

Acknowledgements We are greatly indebted to Messrs. M. Schellekens, R. S. March and D. Trabant, the U. S. Geological Survey at Fairbanks, and Dr. N. Takeuchi, Research Institute for Humanity and Nature, Kyoto, Japan, for their welcome data supply and valuable advice on our field observation. We express our gratitude to Prof. S. Akasofu, Director of IARC (International Arctic Research Center), University of Alaska 
at Fairbanks for his support in our field survey. We also thank Mr. Y. Shinmyo and Ms.

Y. Freed, staff of IARC, University of Alaska at Fairbanks for their great assistance in our field survey. We are grateful to Mr. M. Sweetsir, President of Yutana Barge Lines, LLC for his great help in the field survey. This study was financially supported as part of the Yukon Water and Energy Budget Experiment (YuWEX) Project (supervisor, Dr. N. Ishikawa, Institute of Low Temperature Science, Hokkaido University), Japan Marine Science and Technology Center (JAMSTEC). The two reviewers, Dr. M. Sharp, the University of Alberta, and Dr. D. de Boer, the University of Saskatchewan, gave many constructive criticisms to this manuscript.

\section{REFERENCES}

Alley RB, Cully KB, Evenson EB, Strasser JC, Lawson DE, Larson GJ. 1998. How glaciers entrain and transport basal sediment: physical constraints. Quaternary Science Reviews 16: 1017-1038.

Anderson SP, Humphrey NF. 1999. Physical and chemical characterization of spring flood event, Bench Glacier, Alaska, U. S. A.: evidence for water storage. Journal of Glaciology 45: 177-189.

Asselman, HEM. 2000. Fitting and interpretation of sediment rating curves. Journal of Hydrology 234: 228-248. 
Braithwaite RJ. 1995. Positive degree-day factors for ablation on the Greenland ice sheet studied by energy balance modeling. Journal of Glaciology 41: 153-160.

Chikita KA. 1993. A comparative study on suspended sediment discharge initiated by snow- or glacier-melting. IAHS Publications 217: 257-267.

Chikita KA, Nakamichi Y, Smith ND, Perez-Arlucea M. 1998. A comparative study on suspended sediment discharge of rivers. Geophysical Bulletin of Hokkaido University 61: 1-10.

Chikita KA, Kemnitz R, Kumai R. 2002. Characteristics of sediment discharge in the subarctic Yukon River, Alaska. Catena 48: 235-253.

Fountain AG, Walder JS. 1998. Water flow through temperate glaciers. Reviews of Geophysics 36: 299-328.

Gurnell AM. 1993. How many reservoirs? An analysis of flow recessions from a glacier basin. Journal of Glaciology 39: 409-414.

Gurnell AM, Hannah D, Lawler DM. 1996. Sediment yield from glacier basins. In: Erosion and Sediment Yield: Global and Regional Perspectives (ed. By D. E. Walling \& B. W. Webb), 97-104. IAHS Publication 236, IAHS Press, Wallingford, UK.

Hannah DM, Gurnell AM. 2001. A conceptual, linear reservoir runoff model to investigate melt season changes in cirque glacier hydrology. Journal of 
Hydrology 246: 123-141.

Hubbard B, Nienow P. 1998. Alpine subglacial hydrology. Quaternary Science Reviews 16: 939-955.

Kamb B. 1987. Glacier surge mechanism based on linked cavity configuration of the basal water conduit system. Journal of Geophysical Research 92: 9083-9100.

March RS. 2000. Mass balance, meteorological, ice motion, surface altitude, runoff and ice thickness data at Gulkana Glacier, Alaska, 1995 balance year. Water-Resources Investigations Report 00-4074, U. S. Geological Survey, 33 pp.

Matsumoto T. 2003. Hydrological characteristics and their seasonal changes of drainage systems of maritime temperate glaciers. Ph.D. Thesis, Hokkaido University, Sapporo, Japan, 117pp.

Mizunuma K, Chiu C-L. 1985. Prediction of combined snowmelt and rainfall runoff. Journal of Hydraulic Engineering, Am. Soc. Civ. Eng. 111: 179-193.

Morgan, RPC. 1995. Soil Erosion and Conservation. $2^{\text {nd }}$ ed., Longman, London, 298pp.

Motoyama H, Kobayashi D, Kojima K. 1983. Water balance at a small watershed during the snowmelt season. Low Temperature Science, ser. A 42: 135-146.

Nienow P, Sharp M, Wills I. 1998. Seasonal changes in the morphology of the subglacial drainage system, Haut Glacier d'Arolla, Switzerland. Earth Surface and Landforms 23: 825-843. 
Osawa K, Sakai K. 2002. Construction of the suspended sediment runoff model for rainfall-sediment runoff analysis. Transactions of the Japanese Society of Irrigation, Drainage, and Reclamation Engineering 208: 165-172.

Raymond CF, Benedict RJ, Harrison WD, Echelmeyer KA, Sturm M. 1995. Hydrological discharges and motion of Fels and Black Rapids Glacier, Alaska, U. S. A.: implication for the structure of their drainage systems. Journal of Glaciology 41: 290-304.

Sugawara M. 1972. A Method for Runoff Analysis. Kyoritsu Shuppan Press, Tokyo (in Japanese).

Tranter M, Brown GH, Hodson A, Gurnell AM. 1996. Hydrochemistry as an indicator of subglacial drainage system structure: a comparison of alpine and sub-polar environments. Hydrological Processes 10: 541-556.

Wagnon P, Ribstein P, Schuler T, Francou B. 1998. Flow separation on Zongo Glacier Cordillera Real, Bolivia. Hydrological Processes 12: 1911-1926.

Walder JS, Fowler AC. 1994. Channelized subglacial drainage over a deformable bed. Journal of Glaciology 40: 3-15.

Walling, DE. 1974. Suspended sediment and solute yields from a small catchment prior to urbanization. In: Gregory, K. J., Walling, D. E. (eds), Fluvial processes in instrumented watersheds, Institute of British geographers special publication 6, 169-192. 
Willis IC, Richards KS, Sharp MJ. 1996. Links between proglacial stream suspended sediment dynamics, glacier hydrology and glacier motion at Midtdalsbreen, Norway. Hydrological Processes 10: 629-648.

Yue S, Hashino M. 2000. Unit hydrographs to model quick and slow runoff components of streamflow. Journal of Hydrology 227: 195-206. 


\section{Figure Legend}

Figure 1. Location of Gulkana Glacier in the drainage basin (dashed line) of the Tanana River, Alaska (Left) and observation sites (site WS and site PC) in the headwater region including the glacier (modified after March 2000)

Figure 2. Temporal variations of discharge, sediment load, water temperature, suspended sediment concentration, air temperature and rainfall at site PC.

Figure 3. Sediment rating curve. $\times$ : first event, $\bigcirc$ : second event, $\bigcirc$ : the other periods

Figure 4. Temporal variations of discharge and sediment load during three successive recession periods

Figure 5. Temporal variations of specific discharge, water input and cumulative water storage

Figure 6. Combination of tanks for simulating discharge

Figure 7. Comparison between simulated and observed results. Three components of the simulated discharge are also described

Figure 8. Tank collapse supposed for the events

Figure 9. Comparison between simulated and observed results. The four components, $Q_{\text {fast }}, Q_{\text {slow }}, Q_{\text {collapse }}$ and $Q_{n}$ of the simulated total discharge, $Q+Q_{\text {collapse }}$, are also described for their comparison

Figure 10. Tank combination for sediment load, where the collapse of a subglacial reservoir in the events is supposed.

Figure 11. Comparison between observed and simulated sediment loads (rating approach). Sediment load contribution from the tank collapse is also described

Figure 12. Comparison between observed and simulated sediment loads (separation approach). Sediment load contribution of each component except for that from the collapsed tank is also delineated 
Table 1. Seasonal variations of snow line in altitude and correspondent snow-covered and ice-covered areas

\begin{tabular}{cccc}
\hline Period & $\begin{array}{c}\text { Snow line* } \\
\text { (m a.m.s.l.) }\end{array}$ & $\begin{array}{c}\text { Snow-covered area } \\
\left(\mathrm{km}^{2}\right)\end{array}$ & $\begin{array}{c}\text { Ice-covered area } \\
\left(\mathrm{km}^{2}\right)\end{array}$ \\
\hline 1 to 15 June & 1350 & 18.7 & 1.1 \\
16 to 30 June & 1500 & 17.0 & 2.8 \\
1 to 31 July & 1600 & 15.8 & 4.0 \\
1 to 31 August & 1700 & 13.8 & 6.0 \\
\hline
\end{tabular}

* after N. Takeuchi

Table 2. Discharge coefficients $\left(\mathrm{h}^{-1}\right)$ used for the simulation of discharge time series

\begin{tabular}{cccccc}
\hline$D_{\text {slow }}$ & $D_{g l}$ & $D_{n 1}$ & $D_{n 1-2}$ & $D_{n 2}$ & $D_{\text {collapse }}$ \\
\hline 0.015 & 0.051 & 0.20 & 0.01 & 0.05 & 0.01 \\
\hline
\end{tabular}

Table 3. Rating curve parameters

\begin{tabular}{cccccc}
\hline$a_{1}$ & $b_{1}$ & $a_{2}$ & $b_{2}$ & $a_{3}$ & $b_{3}$ \\
\hline 40 & 2 & 150 & 0.8 & 80 & 1.7 \\
\hline
\end{tabular}




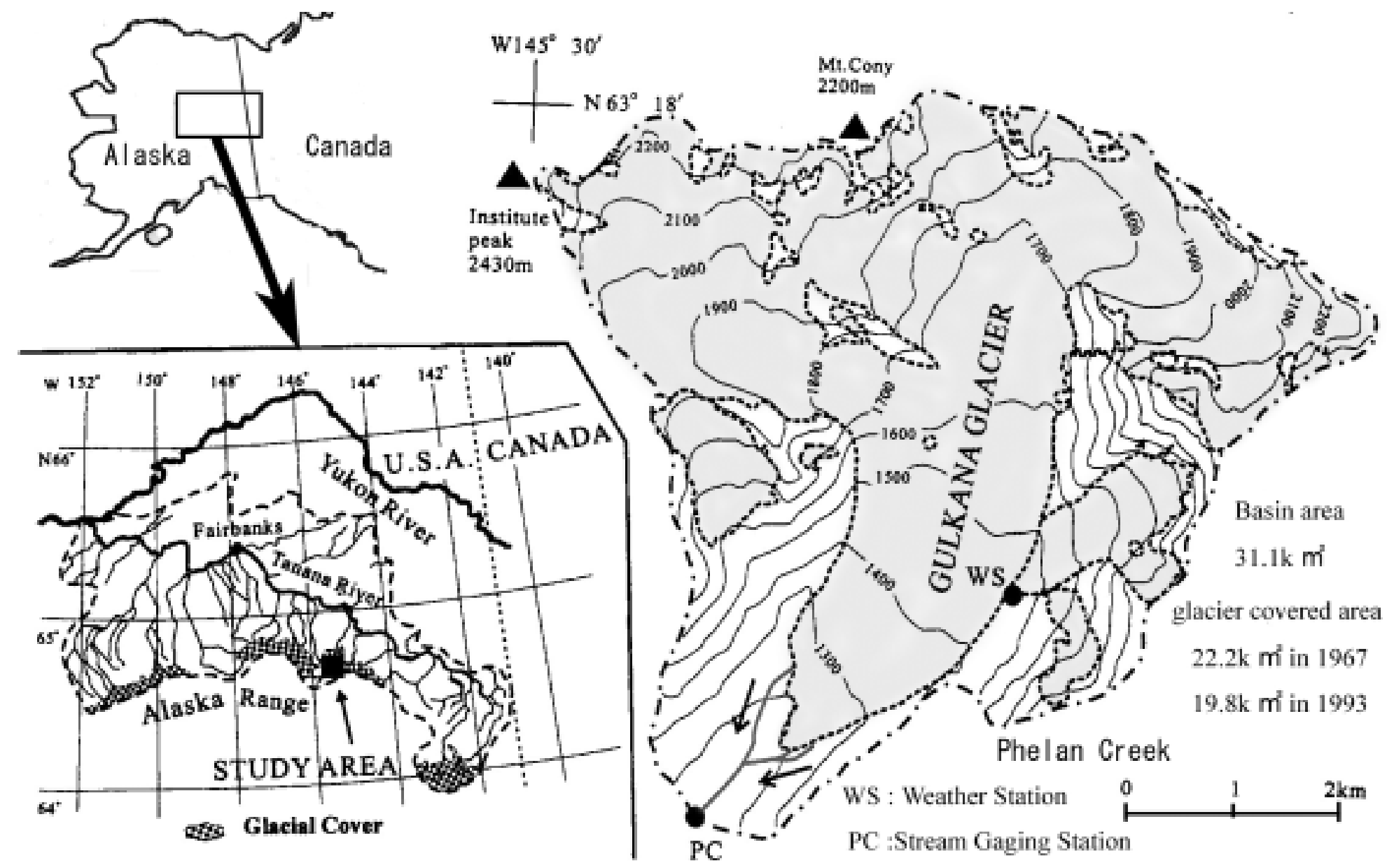

Figure 1. Location of Gulkana Glacier in the drainage basin (dashed line) of the Tanana River, Alaska (Left) and observation sites (site WS and site PC) in the headwater region including the glacier (modified after March 2000) 

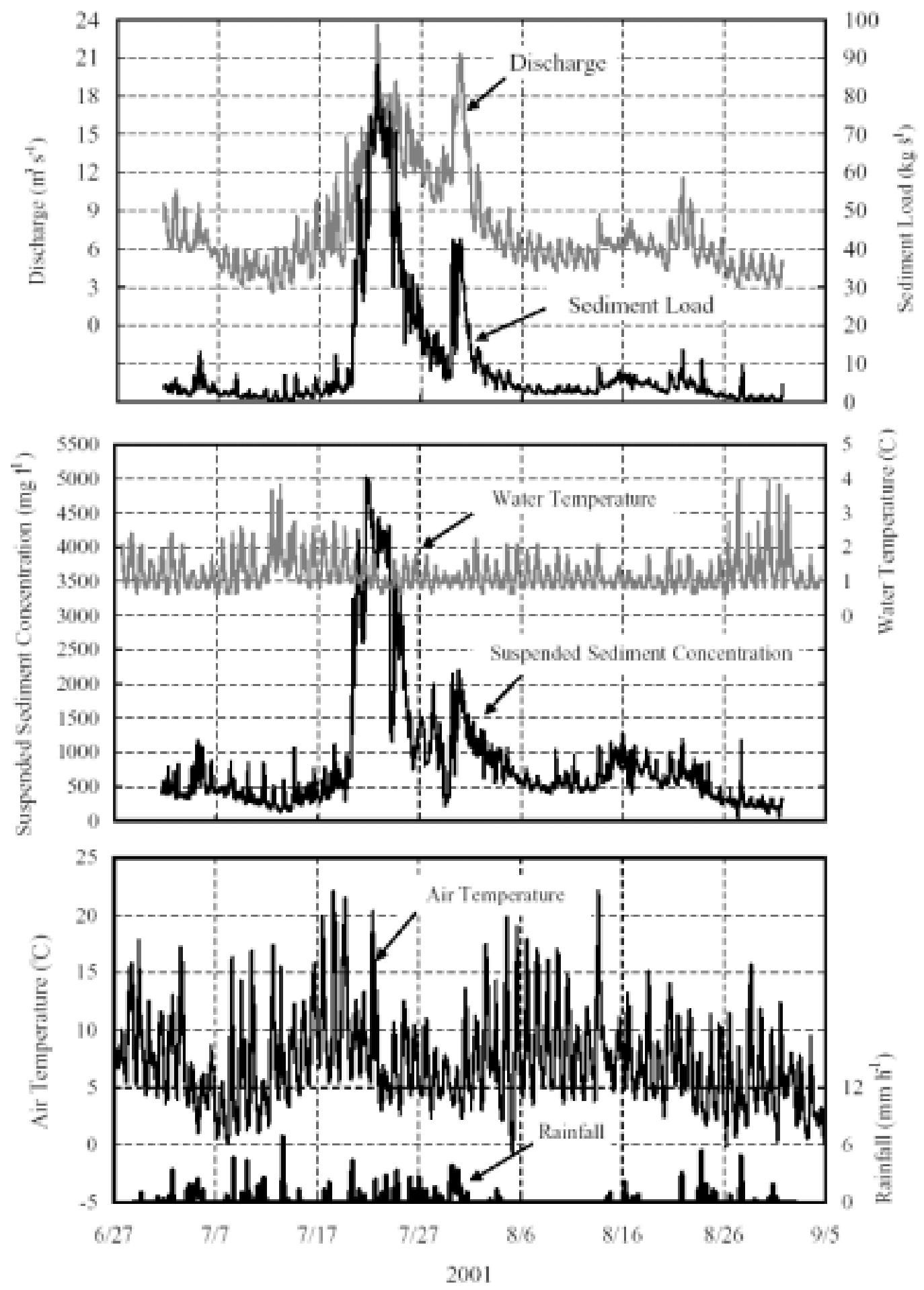

Figure 2. Temporal variations of discharge, sediment load, water temperature, suspended sediment concentration, air temperature and rainfall at site PC 


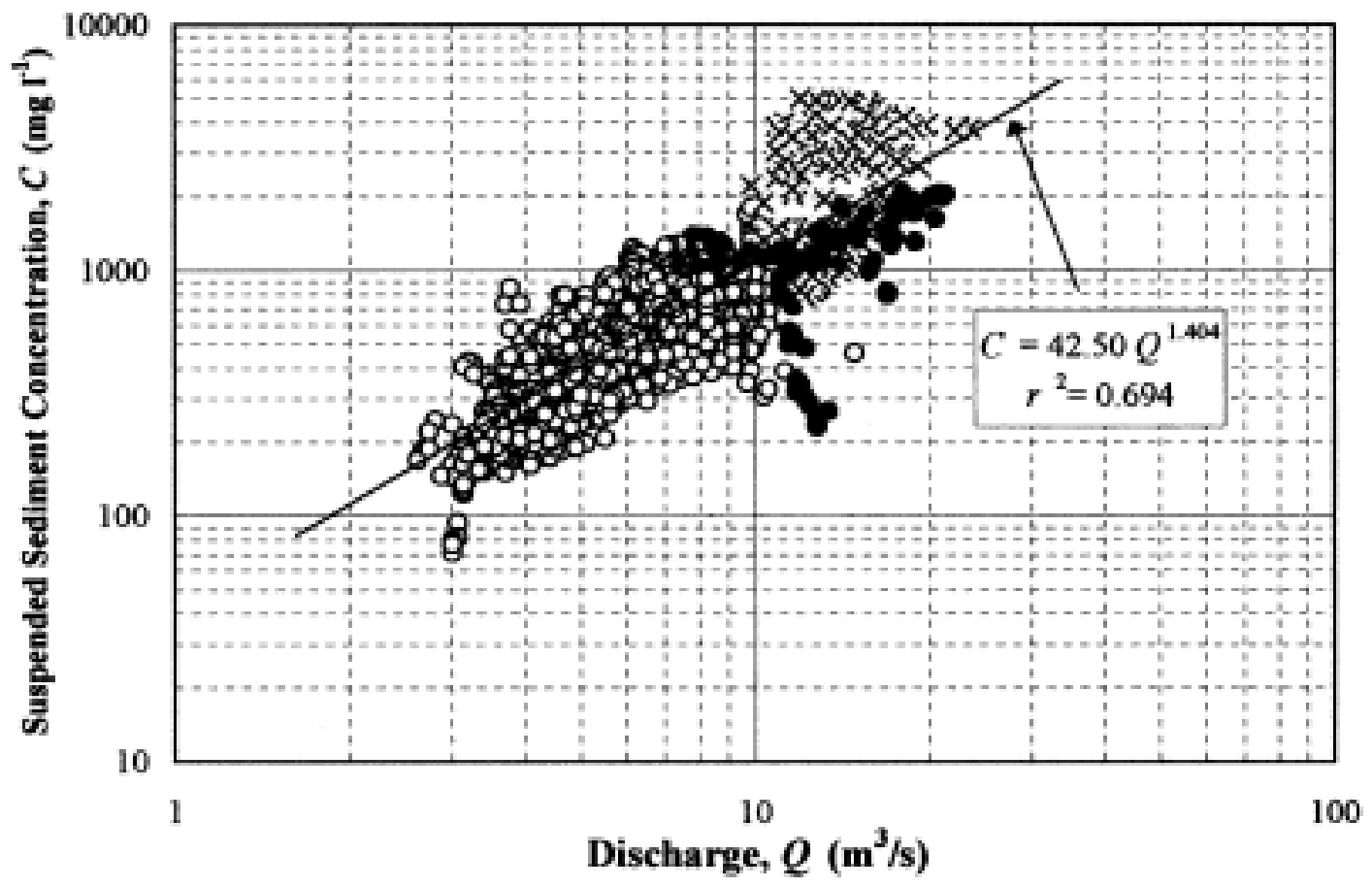

Figure 3. Sediment rating curve. $\times$ : first event, $\bigcirc$ : second event, $\bigcirc$ : the other periods 

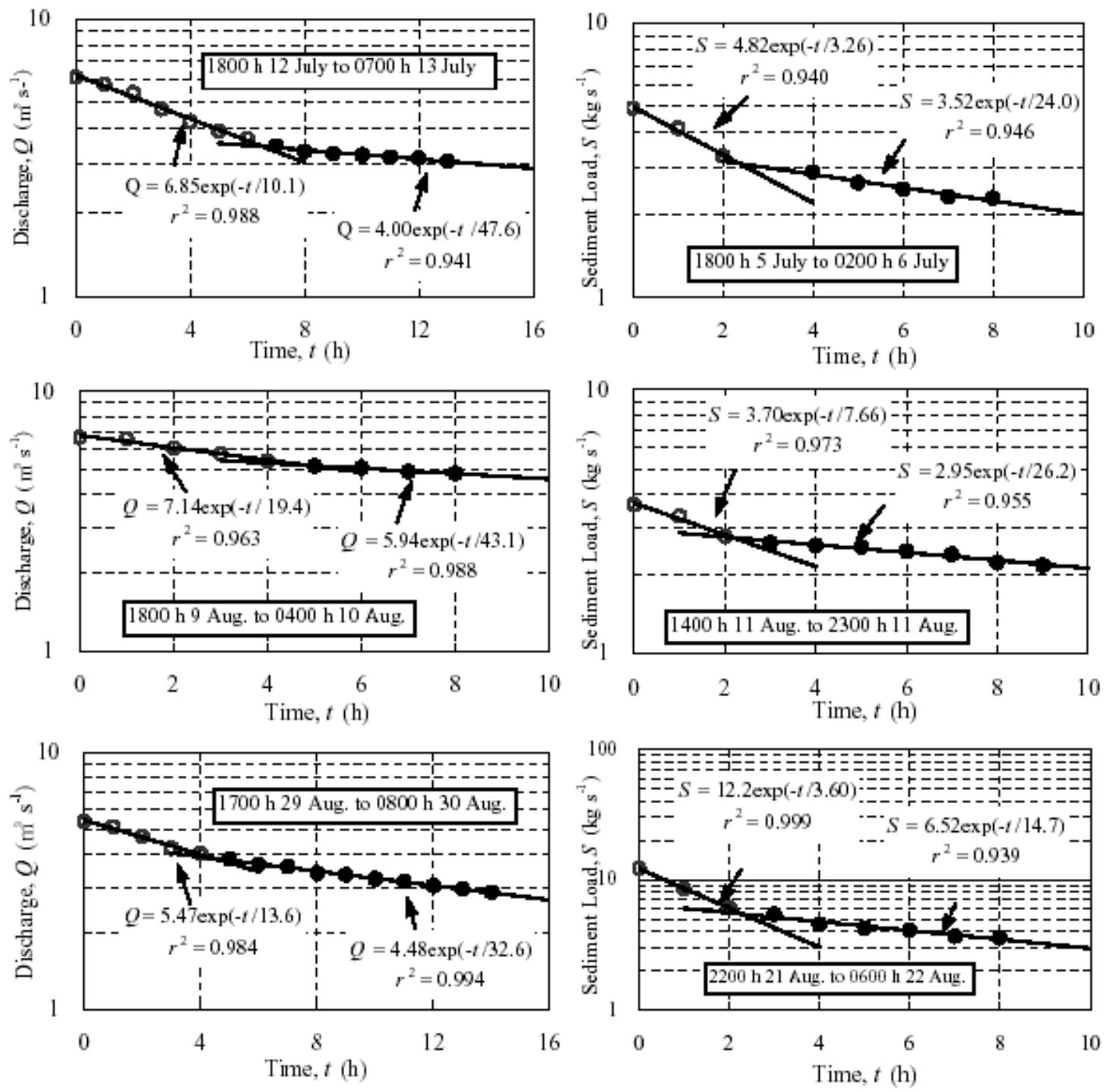

Figure 4. Temporal variations of discharge and sediment load during three successive recession periods 


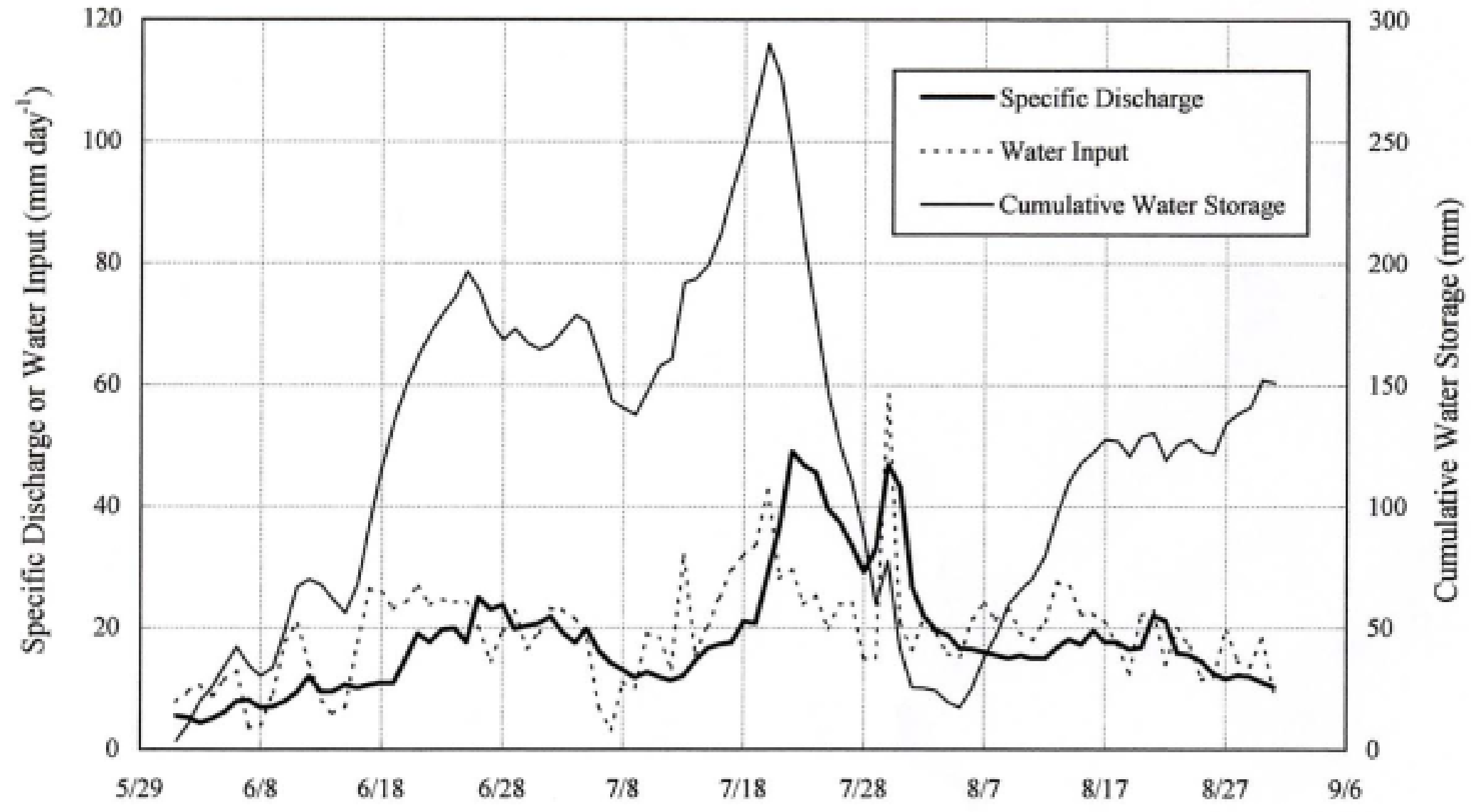

Figure 5. Temporal variations of specific discharge, water input and cumulative water storage 


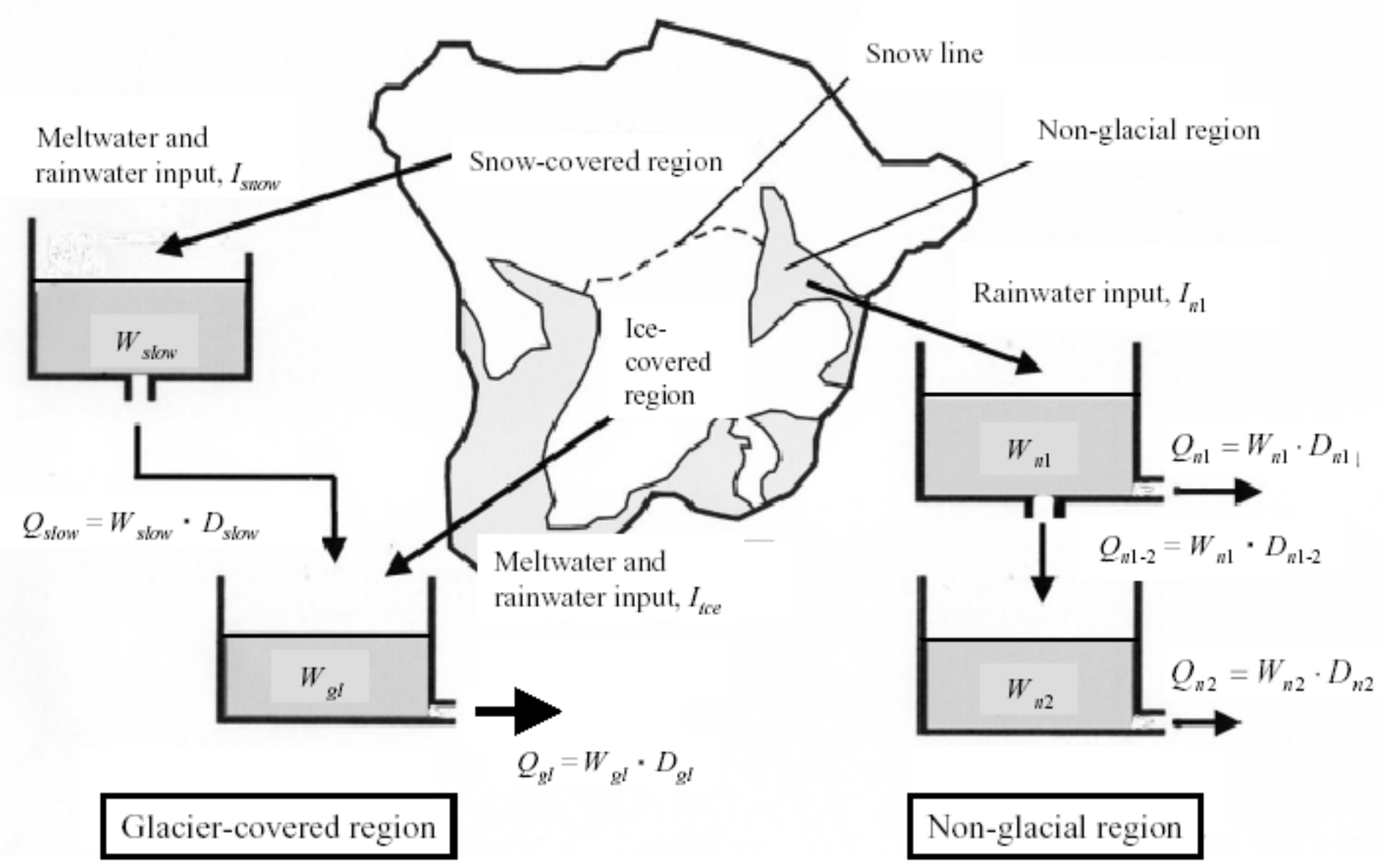

Figure 6. Combination of tanks for simulating discharge 


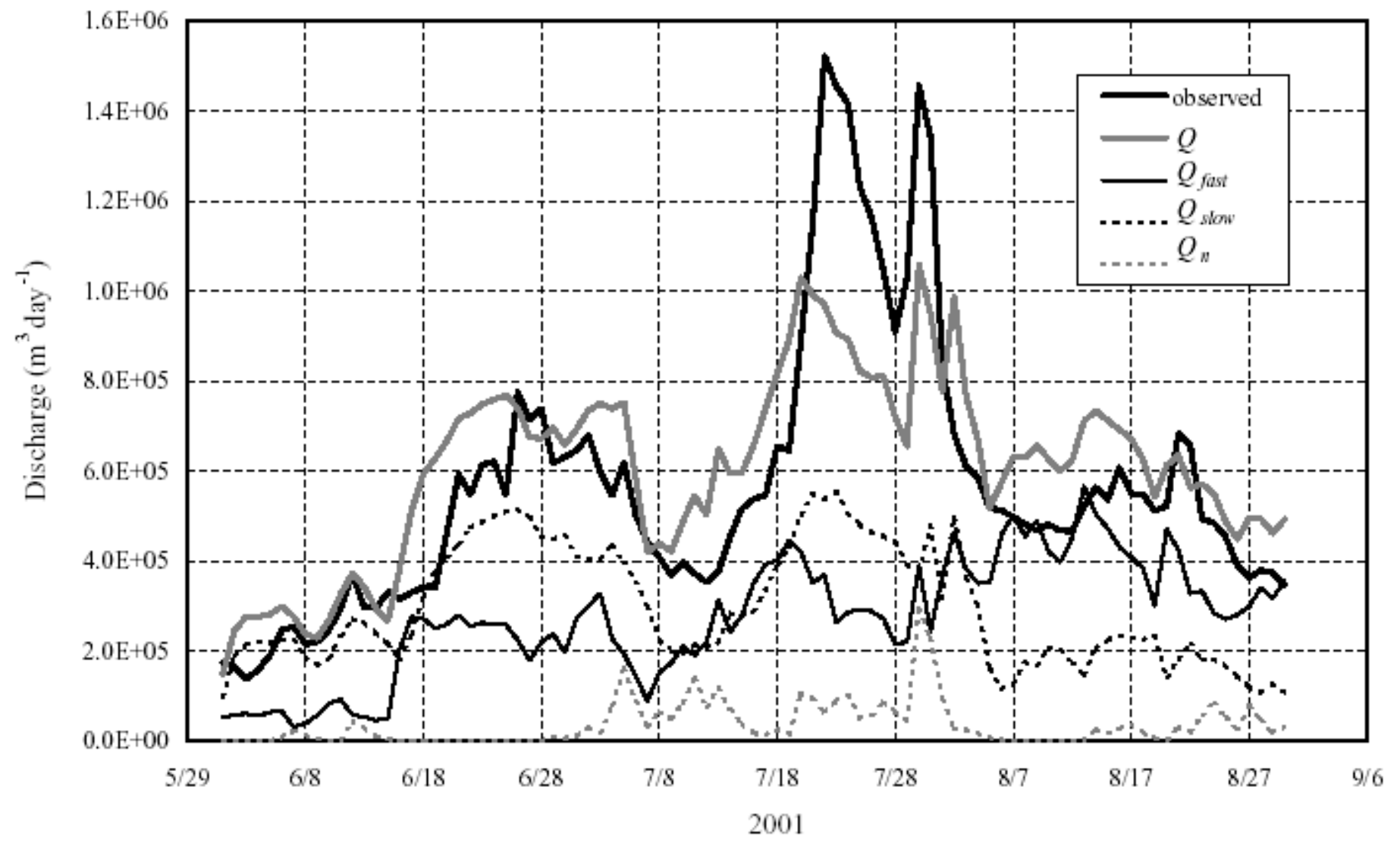

Figure 7. Comparison between simulated and observed results. Three components of the simulated discharge are also described 
Water input in the snow-

covered region $(15 \%$ of total

discharge before 22 June)

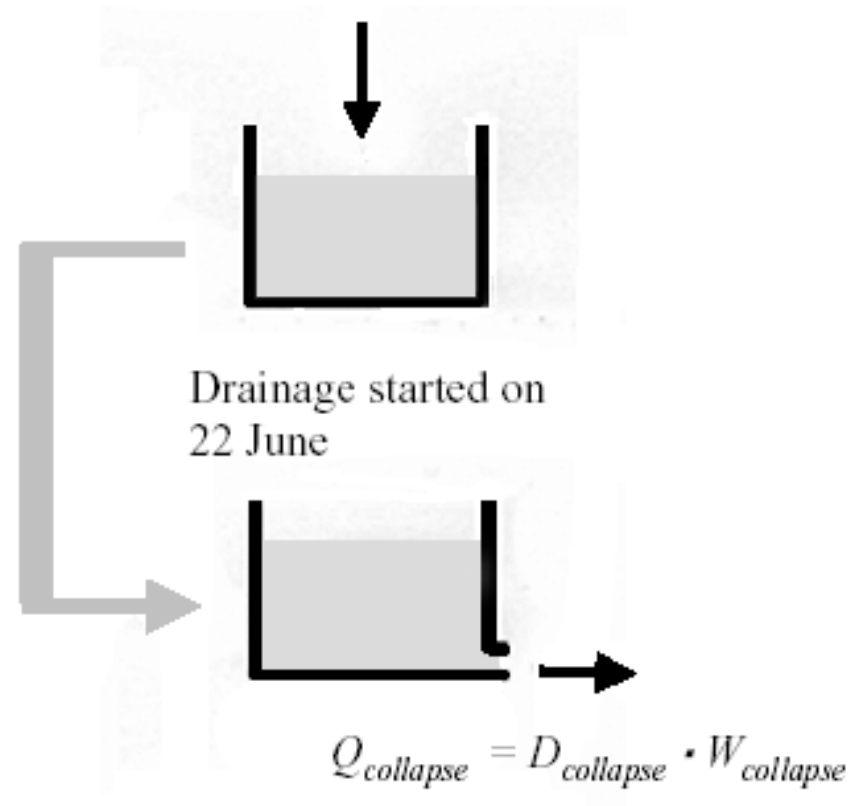

Figure 8. Tank collapse supposed for the events 


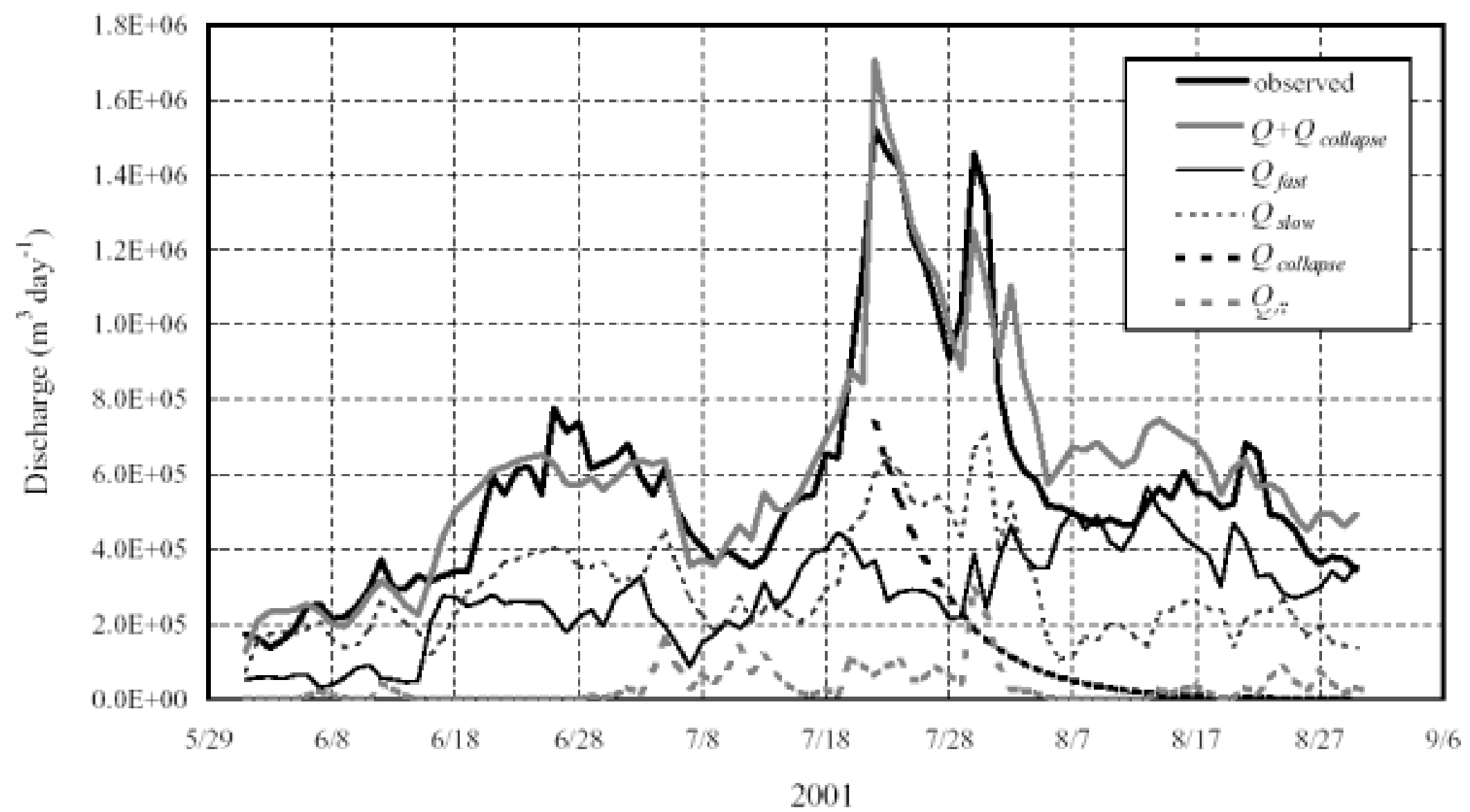

Figure 9. Comparison between simulated and observed results. The four components, $Q_{\text {fast }}, Q_{\text {slow }}, Q_{\text {collapse }}$ and $Q_{n}$ of the simulated total discharge, $Q+Q_{\text {collapse }}$, are also described for their comparison 


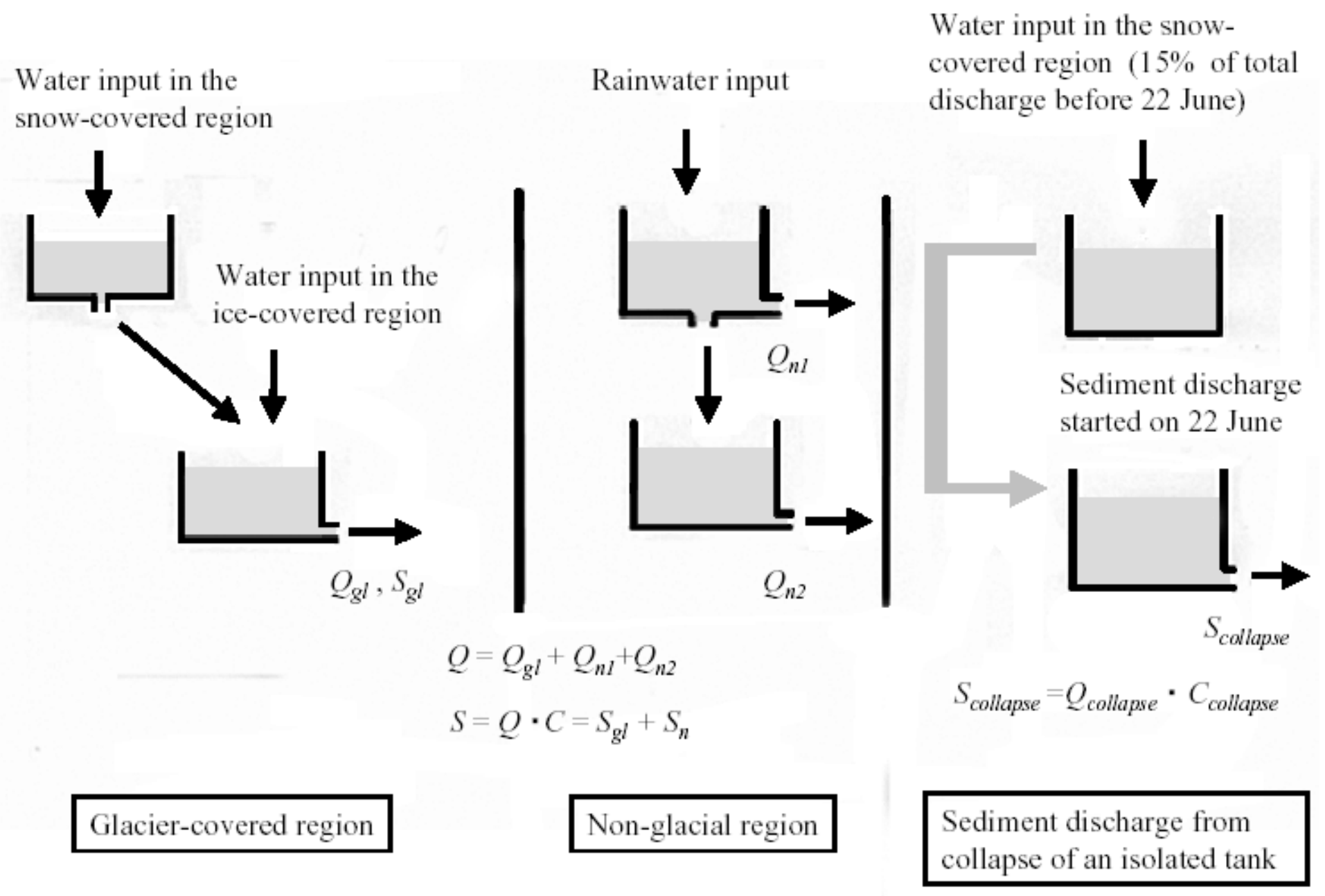

Figure 10. Tank combination for sediment load, where the collapse of a subglacial reservoir in the events is supposed 


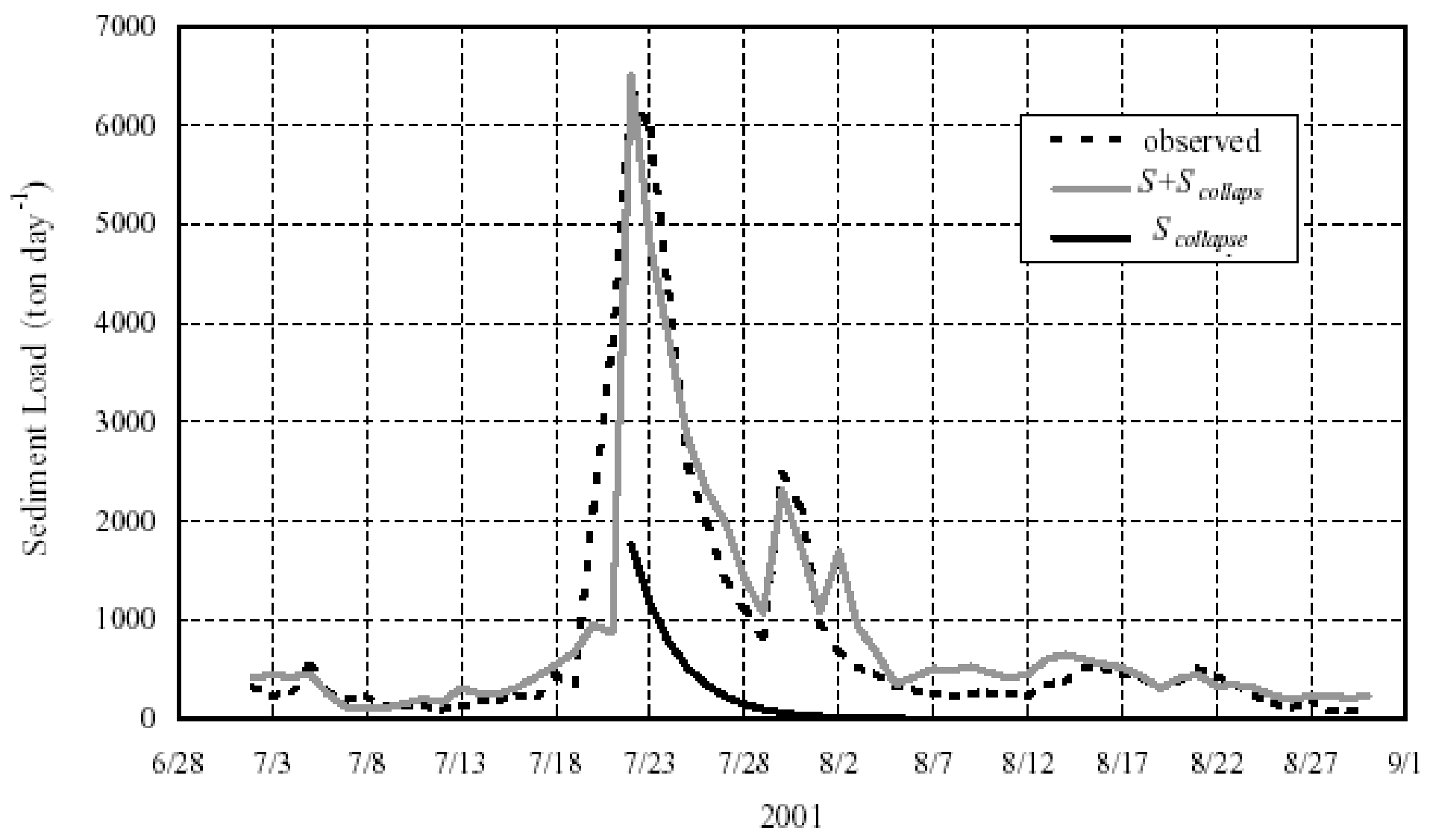

Figure 11. Comparison between observed and simulated sediment loads (rating approach). Sediment load contribution from the tank collapse is also described 


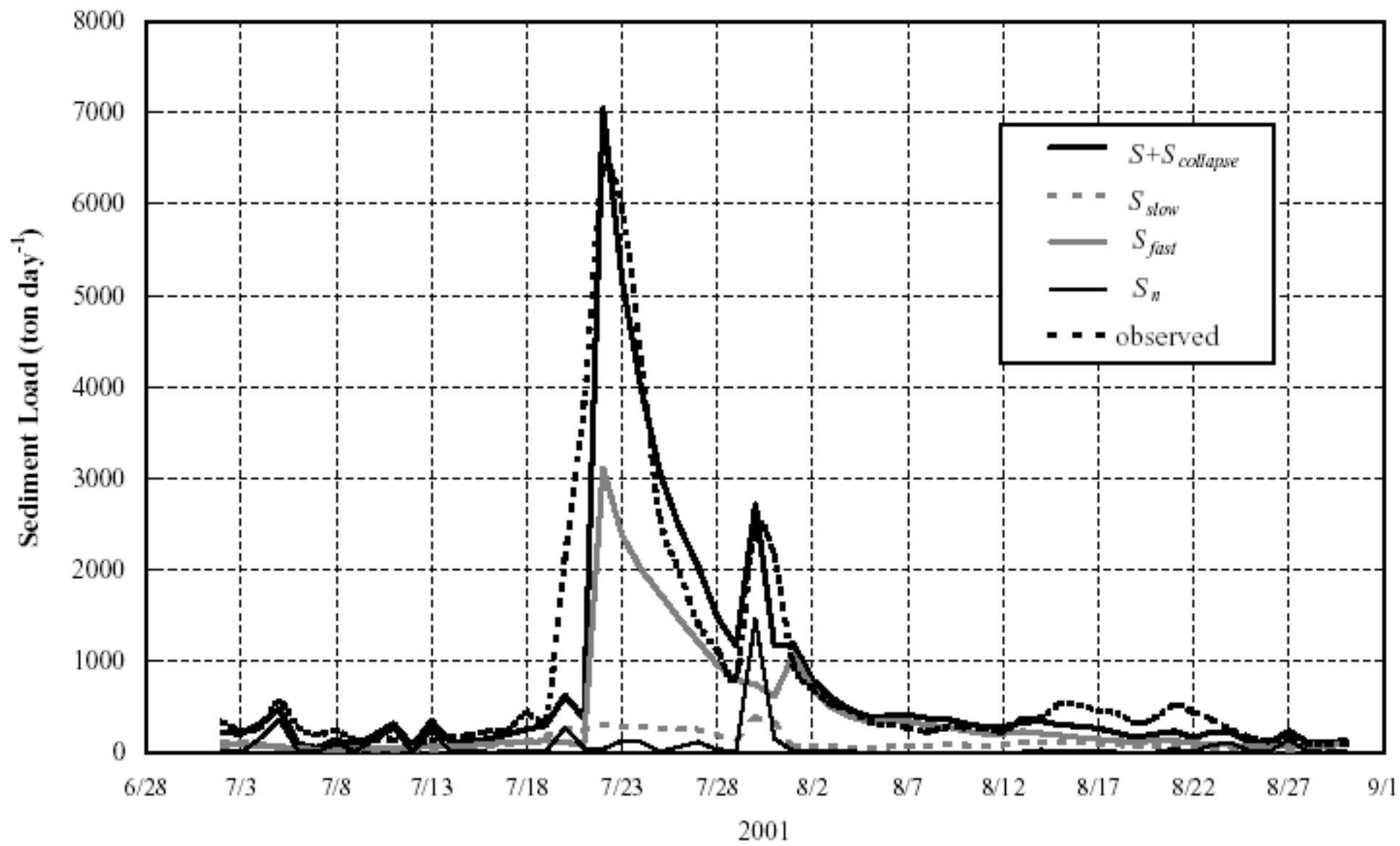

Figure 12. Comparison between observed and simulated sediment loads (separation approach). Sediment load contribution of each component except for that from the collapsed tank is also delineated 